22. Lovska, A. (2018). Simulation of Loads on the Carrying Structure of an Articulated Flat Car in Combined Transportation. International Journal of Engineering \& Technology, 7 (4.3), 140. doi: https://doi.org/10.14419/ijet.v7i4.3.19724

23. Fomin, O., Gerlici, J., Lovska, A., Kravchenko, K., Prokopenko, P., Fomina, A., Hauser, V. (2019). Durability Determination of the Bearing Structure of an Open Freight Wagon Body Made of Round Pipes during its Transportation on the Railway Ferry. Communications - Scientific Letters of the University of Zilina, 21 (1), 28-34.

24. Kučera, P., Piššěk, V. (2017). Testing of the mechatronic robotic system of the differential lock control on a truck. International Journal of Advanced Robotic Systems, 14 (5), 172988141773689. doi: https://doi.org/10.1177/1729881417736897

25. Pistek, V., Klimes, L., Mauder, T., Kucera, P. (2017). Optimal design of structure in rheological models: an automotive application to dampers with high viscosity silicone fluids. Journal of Vibroengineering, 19 (6), 4459-4470. doi: https://doi.org/10.21595/jve.2017.18348

26. Lukin, V. V., Shadur, L. A., Koturanov, V. I., Hohlov, A. A., Anisimov, P. S. (2000). Konstruirovanie i raschet vagonov. Moscow, 731.

27. Vatulia, G., Falendysh, A., Orel, Y., Pavliuchenkov, M. (2017). Structural Improvements in a Tank Wagon with Modern Software Packages. Procedia Engineering, 187, 301-307. doi: https://doi.org/10.1016/j.proeng.2017.04.379

28. Molotnikov, V. Ya. (2017). Tehnicheskaya mehanika. Sankt-Peterburg, 476.

29. Filatov, Yu. E. (2017). Vvedenie v mehaniku materialov i konstruktsiy. Sankt-Peterburg, 320.

30. DSTU 7598:2014. Vaho ny vantazhni. Zahalni vymohy do rozrakhunkiv ta proektuvannia novykh i modernizovanykh vahoniv koliyi $1520 \mathrm{~mm}$ (nesamokhidnykh) (2015). Kyiv, 162.

31. GOST 33211-2014. Vagony gruzovye. Trebovaniya k prochnosti i dinamicheskim kachestvam (2016). Moscow, 54.

32. BS EN 12663-2. Railway applications. Structural requirements of railway vehicle bodies. Freight wagons (2010). British Standards Document. doi: https://doi.org/10.3403/30152552u

\begin{abstract}
Розроблена нова форма тандемної лопаті з вдосконаленим розташуванням профілів по відношенню до відомих гвинтів, в яких профілі розташовуються подібно до тандемного крила літака. Запропоновано нове розташування профілів по висоті лопаті. За основу для проектування було взяте розташування профілів подібне до тандемних лопаткових вінців компресорів та вентиляторів. Такий підхід дозволив ліквідувати аеродинамічне затінення лопатей та підвищити їхню аеродинамічну навантаженність. Для об'єднання лопатей в кінцевій частині застосована спіралеподібна перетинка, яка дозволила значно знизити кінцеві вторинні втрати за рахунок запобігання утворення кінщевого вихору.

Для дослідження характеристик тандемних гвинтів та структури газодинамічної течії навколо них розроблена розрахункова модель гвинта в періодичній постановці, що дозволило значно скоротити час розрахунку. Моделювання здійснювалось в програмному комплексі ANSYS CFX, в якому реалізований алгоритм вирішення нестаціонарних осереднених по Рейнольдсу рівнянь Нав'є-Стокса замкнутих моделлю турбулентності SST Ментера. В результаті моделювання отримані характеристики тандемного гвинта, які підтвердили правильність вибраного підходу щодо проектування тандемної лопаті. ККД розробленого гвинта досягає рівня 75 \% на розрахунковому режимі, що є дуже хорошим показником для малорозмірних гвинтів, які прачюють при низьких значеннях числа Рейнольдса. Для порівняння, ККД класичних, подібних по геометричним характеристикам гвинтів, знаходиться в межах 50-60 \%. При використанні тандемного гвинта з об'єднаними лопатями як штовхаюочого рушія відзначено зниження його тяги на рівні 3-4 \%, що обумовлено утворенням зони розрідження у втулковій частині та в області кока

Ключові слова: повітряний гвинт, кінщевий вихор, стрічка Мьобіуса, коробчатий гвинт, тандемний гвинт $\square$ 口
\end{abstract}

Received date 22.01.2020 Accepted date 20.03.2020 Published date 24.04.2020
UDC 629.7.035.7

DOI: $10.15587 / 1729-4061.2020 .199486$

\section{A NUMERICAL STUDY OF PERFORMANCE OF THE SMALL-SIZE UAV PUSHING TANDEM PROPELLER WITH JOINED BLADES}

\author{
M. K u l y k \\ Doctor of Technical Sciences, \\ Professor, Head of Department* \\ F. Ki r c h u \\ $\mathrm{PhD}$, Associate Professor* \\ E-mail: fkirchu@gmail.com \\ Hussein Hanesh \\ Postgraduate Student* \\ *Department of Aviation Engines \\ National Aviation University \\ Liubomyra Huzara ave., 1, \\ Kyiv, Ukraine, 03058
}

\section{Introduction}

The propeller, as a thruster, has been known for a very long time and has been the only possible mover in aviation for many years. The increase in flight speed, the emergence of jet, and then turbofan gas turbine engines significantly reduced the use of propellers. However, it should be noted that today the propeller has no competitors in terms of profitability at moderate flight speeds $(M \leq 0.6$, and in the case of coaxial counter-rotating fans, $M \leq 0.8)$. Also, propellers 
have no competitors in the application on wing-in-ground effect crafts and air-cushion ships, where it is necessary that the propeller throw a large mass of air at a low speed, which is impossible to achieve with jet engines. The main disadvantages of propellers that limit their use include low aerodynamic loading (limited by the number of blades), significant diametric dimensions, the need for a gearbox and a mechanism for the blade pitch change, significant tip losses (associated with the formation of tip vortices and their interaction between each other and with the airplane).

However, despite the inherent disadvantages, an increased interest in propellers as thruster has recently begun to show. This is mainly due to the rapid development of subsonic unmanned aircrafts and methods of numerical gas dynamics, the use of which allows more efficient (optimal) design and research. Also in recent years, the interest of designers in the "open rotor" system with multi-blade wide-chord counter-rotating propellers has increased significantly.

In general, modern tandem counter-rotating propellers have an optimal ratio between aerodynamic loading on the blade and the level of secondary losses; however, they have a complex structure and require the use of powerful gearboxes for their rotation.

The intermediate position between single-row and double-row counter-rotating propellers is occupied by spiral and tandem propellers. Tandem propellers are conceptually similar to a biplane wing, and joining of the blades should theoretically lead to a significant decrease in the intensity of the tip vortex and increase the aerodynamic loading of the blade compared to the classical design of the propeller.

Thus, the task of finding and researching ways and methods of reducing the level of propeller tip losses is constantly relevant, and the tandem scheme looks quite attractive from the point of view of the ratio of overall dimensions and efficiency. For small UAV propellers, the task of increasing their efficiency is even more relevant, since they work at low Reynolds numbers $\left(\mathrm{Re}=10^{4}-10^{5}\right)$. Unlike propellers operating at large Reynolds numbers $\left(\operatorname{Re}>10^{6}, \eta=0.8-0.9\right)$, their efficiency is much lower $(\eta=0.4-0.6)$.

In general, it should be noted that tandem propellers allow a comprehensive approach to solving the problem of efficiency and reducing weight and size characteristics, however, along with the known advantages, theoretical methods for their design are practically absent, which creates significant difficulties in the design and use of such propellers. This is primarily due to the practical lack of research results on tandem propellers with joined blades, and the results of existing research are only partial and do not provide a complete picture of the aerodynamic characteristics and flow characteristics of tandem propellers. Most of all it concerns the flow around the hub and tip parts of the propeller where the flow has a pronounced three-dimensional character. Therefore, studies aimed at determining the aerodynamic characteristics and flow characteristics of tandem propellers with joined blades are relevant and timely, since their results will subsequently determine the factors affecting their characteristics and develop methods for designing such propellers.

\section{Literature review and problem statement}

The main problem of modern propellers is that to reduce the weight and size characteristics and increase the aerody- namic loading of the propeller blades, an increase in peripheral velocity is necessary, which leads to a forced decrease in the diameter dimensions, and this in turn reduces the thrust that the propeller produces. This circumstance forces us to use wide-chord blades with a small aspect ratio and the scheme of counter-rotating propellers. An intermediate place is occupied by tandem propellers, which were developed in the early 1950s. However, like wide-chord blades with low aspect ratio, tandem propellers have one significant disadvantage - a significant level of secondary losses, which are caused by the tip vortex flows, which are formed as a result of the air flow in the tip part of the blade.

The solution to the problem of improving the propeller efficiency goes in different ways. It depends on the design and scheme of the propeller. There is a whole direction of research aimed at reducing the secondary losses of propellers due to the tip effects. In [1], to reduce the tip losses of propellers, the end of the blade is specially shaped. In $[2,3]$, studies on the use of finite plates are presented. In [4], it was proposed to install a number of stationary blades located downstream of the propeller for the untwisting of the tip vortex. Such measures can reduce secondary losses and increase propeller efficiency by an average of $3-5 \%$, but they do not solve the problem of propeller dimensions and increase the aerodynamic loading on the blade. In [5], it was proposed to use forward swept blades. This approach allows you to increase aerodynamic loading and reduce secondary propeller losses. However, from the operation point of view, a significant torque is acting on the forward swept blades, which leads to a change in the propeller blade geometry during operation and the intensification of aeroelastic vibrations.

Another approach is the use of wide-chord blades and counter-rotating double row propellers. It allows you to reduce the diametrical dimensions and increase the aerodynamic load on the rotor blade. However, when applying a multiblade scheme with wide-chord blades of small aspect ratio, secondary losses rapidly increase due to the increased intensity and interaction of the tip vortices. The work [6] presents studies of counter-rotating propellers with different sweeps of the first and second rows of blades. For the first row, a backward sweep is used, and for the second - forward sweep. The different diameters of the first and second rows and the optimal location along the axis of rotation of the first and second rows of blades can reduce secondary losses. However, despite such measures, the final losses in the counter-rotating propellers are quite significant, and the interaction of the final vortices with the rotor blades and between them leads to an increase in acoustic emission compared to single-row propellers. To solve these problems, it was proposed in [7] to use a blade in the form of a spiral, which, according to the authors, will reduce the tip losses. In general, this design allows to reduce the tip loss, however, to an insignificant level, since a pressure differential from one or the other side of the blade will still be present. In [8], to reduce the pressure drop, it was proposed to use a blade in the form of a Moebius band. Such a blade can significantly reduce secondary losses, however, along with this, the aerodynamic load on the blade is also reduced. This is due to the fact that the front part of the blade is fully loaded, but the rear part is underloaded, due to the shape of the blade. A similar propeller design is considered in [9]. The main difference is that the blade, which is also made of tape, joins its ends 
on the hub and forms a pair of loops in the form of figure eight around its longitudinal axis. A common disadvantage of [7-9] is that they show only the design of the propellers, the rationale and the expected effect of their use, but the results of numerical and experimental studies confirming such statements are completely absent. Also, analysis of the proposed designs showed that a significant axial overall size and the inability to apply the mechanism of the blade pitch changing eliminates their advantages. A tip vortex in such propellers will also be present, although of a lower intensity compared to single-row propellers. The blades, which have the form of spirals, are aerodynamically underloaded, which requires an increase in the diametrical dimensions to provide the necessary thrust. An option to solve such problems can be to use two blades located one after another and which are interconnected in the tip and root parts. This approach was proposed in [10], where it was shown that joining of the blades of the first and second rows leads to a halving of the number of final vortices, however, quantitative results are not presented. To evaluate quantitative results, a numerical study of secondary losses was carried out in [11], and an analytical method for calculating secondary losses was developed in [12]. The main disadvantage of the developed method is that it is possible to estimate the tip losses only by the results of numerical or complex experimental studies and it is impossible to apply this method at the design stage. A generalization of the results of the study of tandem propellers of the "Boxprop" type with joined blades is given in [13]. The results of the study show that joining of the blades leads to a slight decrease in secondary losses, and in some operating conditions to their growth compared to the equivalent single-row propeller. A detailed analysis of the design and characteristics of such propellers showed that their disadvantages are associated with the relative position of the joined blades and the shape of the tip end that unites them. The location of the blades proposed in [10-13] leads to mutual shading. This is clearly seen by the location of the profiles in the sections of the joined blade and the pressure distribution on them, which shows that the rear profile is underloaded along the pressure side, and the front one along the rarefaction side, which ultimately leads to underloading of the blade. Profile losses will be twice as much as those of a single-row propeller. All this is due to the location of the profiles relative to one another, as well as the shape of the tip end that connects the blades.

In general, to summarize, it should be noted that in all the considered works that were related to tandem propellers with joined blades, the arrangement of profiles was applied by analogy with the tandem wing, and for the propeller this leads to shading of the rear profile by the front one. Also, not enough attention has been paid to the profiling of the tip end that connects the blades. This led to the fact that the expected reduction in tip losses did not occur. It should also be noted that in the analysis of world scientific publications, only a few scientific studies were found that were directly related to tandem propellers with joined blades. However, despite this, it is necessary to improve the design and study the characteristics of tandem propellers with joined blades, since at the present level of development of science and technology they have good prospects for use on aircrafts, since they allow to obtain a better ratio between efficiency and dimensions compared to classic propellers.

\section{The aim and objectives of the study}

The aim of the study is to determine the quantitative and qualitative characteristics of the tandem propeller with an improved design of joined blades. This will make it possible to assess the correctness of the chosen direction of improving the design and its inherent disadvantages, in the future this will help to form the prospects for the development and use of tandem propellers with joined blades. Systematization of numerical and further experimental studies will allow us to develop a method of profiling and calculation of operational characteristics, which can be used in the design of propellers of similar design.

To achieve the aim, the following objectives were set:

- to develop a geometric model of the tandem propeller with joined blades, taking into account the disadvantages inherent in previous designs that were identified as a result of the analysis;

- to develop a calculation model and conduct numerical modeling of the tandem propeller with joined blades;

- to analyze the data and provide recommendations for further research.

\section{Geometric model of the tandem propeller with} joined blades

When designing propellers, it is necessary to provide:

- the maximum possible increase in aerodynamic load;

- the maximum possible decrease in the intensity of the tip vortex;

- if necessary, it should be possible to design propellers with variable pitch and folding blades.

Taking this into account and considering the design features of tandem propellers, it is proposed to arrange the blade profiles to solve the assigned tasks by analogy with how it was done in tandem blade rows of axial compressors [14-16]. This arrangement allows the most efficient use of two rows of blades. At the same time, starting from the root part and to the blade height $0.75-0.8 R$, it is customary to use the profiles location according to the type of form $-B$, and in the tip part - according to the type of form $-H$ (Fig. 1).

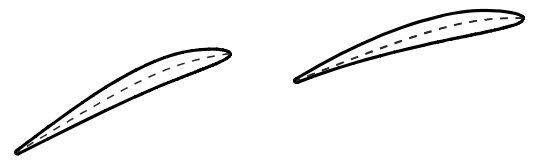

\section{H - Form}

a

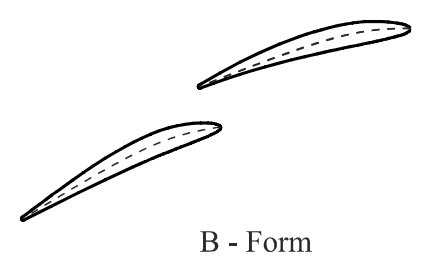

$b$

Fig. 1. Arrangement of profiles: $a-H-$ form; $b-B-$ form

The implementation of this approach, together with the use of the join blades in the tip part, will increase the aerodynamic loading of the blades from the root section to the 
cross-section $0.75-0.8 R$ of the blade height by increasing the twist angle of the flow during continuous (without separation) flow around the blades of the first and second rows. The tip vortex will be utilized (untwisted) by the second row of blades, which is in the shadow of the front row of profiles. And even if the flow stalls on the first row of the blade in the tip part, the second row will continue to work in continuous mode and untwist the vortex that formed from the first row of blades. Structurally, this is achieved through the use of spiral vortex generators, which are installed in the tip parts of the blade and join both rows of blades into one. Both blades in the hub area have a common root part, which allows the use of a mechanism for changing the pitch of the blades, and, if necessary, the folding mechanism of the blades. The first and second rows of blades are made with variable swept along the height.

For research, a pushing propeller was designed for an unmanned aerial vehicle (such as a "flying wing") with the parameters given in Table 1 .

Table 1

Unmanned Aerial Vehicle Parameters

\begin{tabular}{|c|l|c|}
\hline No. & \multicolumn{1}{|c|}{ Parameter } & Value \\
\hline 1 & Take-off weight & $102 \mathrm{~N}$ \\
\hline 2 & Stall speed & $8.3 \mathrm{~m} / \mathrm{s}$ \\
\hline 3 & Cruising speed & $18 \mathrm{~m} / \mathrm{s}$ \\
\hline 4 & Maximum flight speed & $30 \mathrm{~m} / \mathrm{s}$ \\
\hline 5 & Required cruising thrust, at a speed of $18, \mathrm{~m} / \mathrm{s}$ & $\geq 12 \mathrm{~N}$ \\
\hline 6 & Required take-off thrust & $50-60 \mathrm{~N}$ \\
\hline
\end{tabular}

To design a propeller blade, the basic geometric characteristics (Fig. 2) and profile parameters in sections along the blade height were calculated.

Blade profile: BC-10 (10\%); propeller diameter: $406 \mathrm{~mm}$ (16in); propeller hub diameter: $80 \mathrm{~mm}$; number of blades: 4; number of sections: 9 .

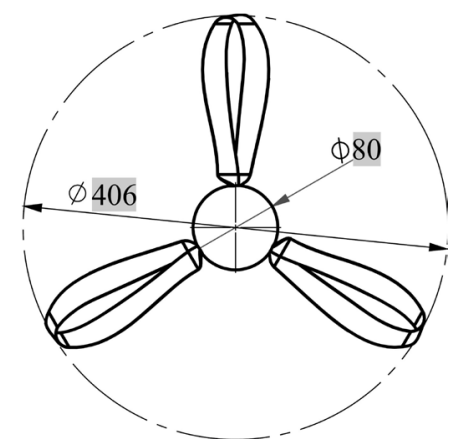

Fig. 2. Basic geometric characteristics of the propeller

For the designed tandem propeller, the arrangement of the profiles along the sections is shown in Fig. 3.

The tandem propeller with joined blades (Fig. 4), which was studied in the work, consists of a propeller hub (pos. 1) and evenly distributed blades (pos. 2), the number of which is two or more. Each individual blade consists of a front blade with backward sweep (pos. 3) and a rear blade with forward sweep (pos. 4).

The front and rear blades are connected at the end by a spiral-like jumper (vortex generator) (pos. 5). In the root part, a spiral-like jumper (pos.6) connecting the blades smoothly passes into the blade attachment unit, which for this propeller configuration (propeller with folding blades) is made like a cylindrical eyelet (pos. 7). Using a pin, each blade is fixed to the propeller hub.
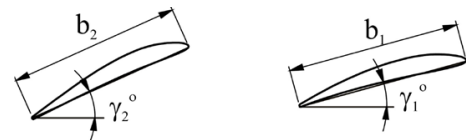

Section 0.9R
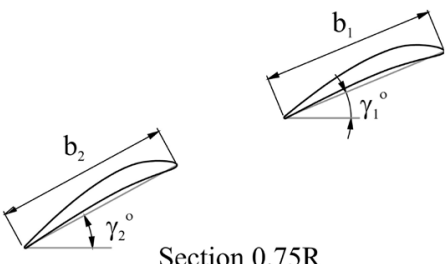

Section $0.75 \mathrm{R}$
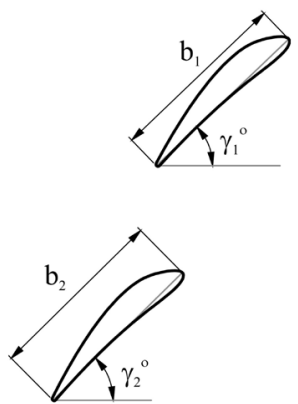

Section $0.25 R$

Fig. 3. Arrangement of profiles in sections along the blade height

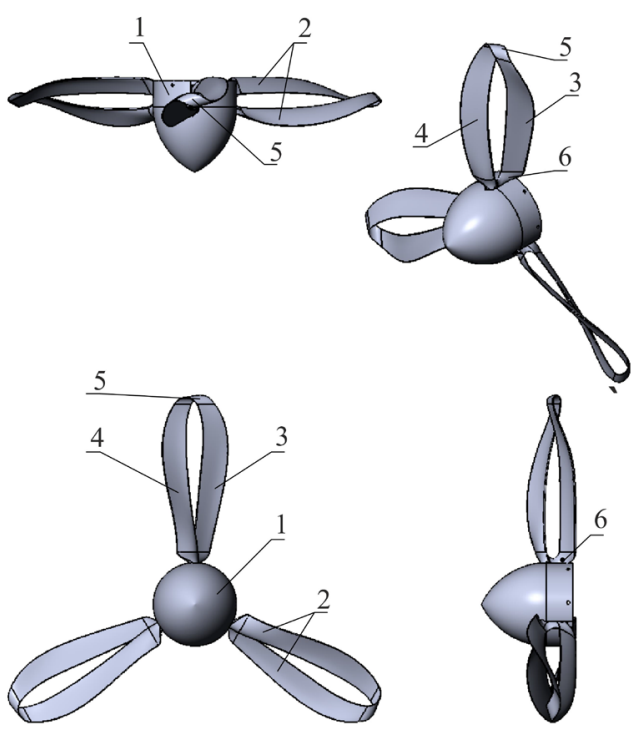

Fig. 4. Tandem propeller with joined blades

\section{Computational model of the tandem propeller with joined blades}

\section{1. Numerical method}

To simulate stationary, viscous and turbulent flows, we used the three-dimensional method of numerical gas dynamics, implemented in the commercial software product ANSYS-CFX 15.07. This program solves non-stationary Reynolds averaged Navier-Stokes equations closed by a turbulence model. 
The main equations that provide a complete mathematical description of the fluid flow are the equations of conservation: mass (1); impulse (2); scalar (energy) (3).

$$
\begin{aligned}
& \frac{\partial \rho}{\partial t}+\frac{\partial}{\partial x_{j}}\left(\rho u_{j}\right)=0 ; \\
& \frac{\partial}{\partial t}\left(\rho u_{j}\right)+\frac{\partial}{\partial x_{j}}\left(\rho u_{i} u_{j}\right)=-\frac{\partial p^{*}}{\partial x_{i}}+ \\
& +\frac{\partial}{\partial x_{j}}\left(\mu_{e f f}\left(\frac{\partial u_{i}}{\partial x_{j}}+\frac{\partial u_{j}}{\partial i}\right)-\frac{2}{3} \mu_{e f f} \frac{\partial u_{i}}{\partial x_{j}} \delta_{i j}\right) ; \\
& \frac{\partial}{\partial t}(\rho H)+\frac{\partial}{\partial x_{j}}\left(\rho u_{j} H\right)=-\frac{\partial p^{*}}{\partial t}+\frac{\partial}{\partial x_{j}}\left(\lambda \frac{\partial T}{\partial x_{j}}+\frac{\mu_{t}}{P r_{i}} \frac{\partial h}{\partial x_{j}}\right)+ \\
& +\frac{\partial}{\partial x_{j}}\left\{u_{i}\left[\mu_{e f f}\left(\frac{\partial u_{i}}{\partial x_{j}}+\frac{\partial u_{j}}{\partial x_{i}}\right)-\frac{2}{3} \mu_{e f f} \frac{\partial u_{k}}{\partial x_{k}} \delta_{i j}\right]+\mu \frac{\partial k}{\partial x_{j}}\right\},
\end{aligned}
$$

where

$$
\mu_{e f f}=\mu+\mu_{t}, p^{*}=p+\frac{2}{3} \rho k
$$

To close the equations, we used the SST turbulent viscosity model in the work [17]. In this model, a smooth transition is organized from the $k$ - $\omega$ model, which well describes shear flows in the near-wall region, to the $k$ - $\varepsilon$ model, which well describes free shear flows. In this case, the kinetic energy transfer equations (4) and the turbulence energy dissipation rates (5) are solved

$$
\begin{aligned}
& \frac{\partial(\rho k)}{\partial t}+\frac{\partial\left(\rho u_{j} k\right)}{\partial x_{j}}=P-\beta^{*} \rho \omega k+\frac{\partial}{\partial x_{j}}\left[\left(\mu+\sigma_{k} \mu_{t}\right) \frac{\partial k}{\partial x_{j}}\right] \\
& \frac{\partial(\rho \omega)}{\partial t}+\frac{\partial\left(\rho u_{j} \omega\right)}{\partial x_{j}}=\frac{\gamma}{V_{t}} P-\beta \rho \omega^{2}+ \\
& +\frac{\partial}{\partial x_{i}}\left[\left(\mu+\sigma_{\omega} \mu_{t}\right) \frac{\partial \omega}{\partial x_{j}}\right]+2\left(1-F_{1}\right) \frac{\rho \sigma_{\omega 2}}{\omega} \frac{\partial k}{\partial x_{j}} \frac{\partial \omega}{\partial x_{j}},
\end{aligned}
$$

where

$$
\begin{aligned}
& P=\tau_{i j} \tau \frac{\partial u_{i}}{\partial x_{j}}, \tau_{i j}=\mu_{t}\left(2 S_{i j}-\frac{2}{3}\right) \\
& \tau_{i j}=\mu_{t}\left(2 S_{i j}-\frac{2}{3} \frac{\partial u_{k}}{\partial x_{k}} \delta_{i j}\right)-\frac{2}{3} \rho k \delta_{i j}, \quad S_{i j}=\frac{1}{2}\left(\frac{\partial u_{i}}{\partial x_{j}}+\frac{\partial u_{j}}{\partial x_{i}}\right) .
\end{aligned}
$$

Turbulent viscosity is calculated by the formula (6)

$$
\mu_{t}=\frac{\rho a_{1} k}{\max \left(a_{1} \omega, \Omega F_{2}\right)} \text {. }
$$

To determine the turbulent viscosity, the mixing function is used (7).

$$
F_{2}=\tanh \left(a_{2}^{2}\right), a_{2}=\max \left(2 \frac{\sqrt{k}}{\beta^{*} \omega d}, \frac{500 v}{d^{2} \omega}\right) .
$$

To switch between models of turbulent viscosity, the mixing function (8) is used, which takes a value of 1 near the wall and 0 outside the boundary layer, as a result of this, the $k$ - $\omega$ model works near the wall, and $k$ - $\varepsilon$ in all other places.

$$
\begin{aligned}
& F_{1}=\tanh \left(a_{1}^{4}\right), \\
& a_{1}=\min \left[\max \left(\frac{\sqrt{k}}{\beta^{*} \omega d}, \frac{500 v}{d^{2} \omega}\right), \frac{4 \rho \sigma_{\omega 2} k}{C D_{k \omega} d^{2}}\right],
\end{aligned}
$$

where

$$
C D_{k \omega}=\max \left(2 \rho \sigma_{\omega 2} \frac{1}{\omega} \frac{\partial k}{\partial x_{j}} \frac{\partial \omega}{\partial x_{j}}, 10^{-10}\right),
$$

$\rho-$ density, $v_{t}=\mu_{t} / \rho-$ kinematic viscosity, $\mu-$ molecular dynamic viscosity, $d$ - distance to the nearest wall.

The constants of the turbulent viscosity model are conventionally divided into two types; regular constants and the second type is a linear combination of constants for the $k-\omega$ and $k-\varepsilon$ models. The combination is carried out using the function $F_{1}$ and equation (9). These constants are denoted by index 3 (for example, $\sigma_{k 3}$ ) and are calculated by the formula (9).

$$
C_{3}=F_{1} C_{1}+\left(1-F_{1}\right) C_{2},
$$

where $C_{1}$ - constants of the model $k-\omega, C_{2}$ - constants of the model $k-\varepsilon$.

The basic constants were used for modeling:

$$
\begin{aligned}
& {\left[\sigma_{k 1}, \sigma_{k 2}, \beta_{1}, \beta_{2}, \beta^{*}, \alpha_{1}, \alpha_{2}, k\right]=} \\
& =[0,85 ; 0.85 ; 0,075 ; 0,0828 ; 0,09 ; 0,55 ; 0,44 ; 0,41] .
\end{aligned}
$$

Significant refinement of the solution of differential equations for separated flows is achieved by limiting the coefficient of turbulent viscosity according to the Bradshaw hypothesis, according to which the shear stresses are proportional to the kinetic energy of turbulence in the entire boundary layer. Function $F_{2}$ is introduced to prevent singularities in the flow core, where the vorticity may tend to zero.

\section{2. Computational domain and boundary conditions}

The simulation was carried out in a periodic computational domain (Fig. 8) including two domains: a stationary domain (Stationary domain) with boundary conditions Inlet, Outlet, Opening, Wall and a rotating domain (Rotating domain) with boundary conditions Wall on the surfaces of the blade and the propeller hub. The domains are combined into the computational domain using the "STAGE" mixing interface.

The boundary conditions were determined on all surfaces of the calculation model and had the following parameters:

Inlet - value and direction of the incoming flow velocity, turbulence intensity, static temperature (corresponded to the International Standard Atmosphere at a given height).

Outlet - static pressure corresponding to ISA at a given height; Opening - static pressure for free flow; Wall - nonslip adiabatic wall (set on the surfaces of the hub and the blade); Rotational periodic - the flow part for one blade was modeled. The opening angle of the domain changed depending on the number of blades and was $180^{\circ}$ for two blades, $120^{\circ}$ for three, and $90^{\circ}$ for four. 


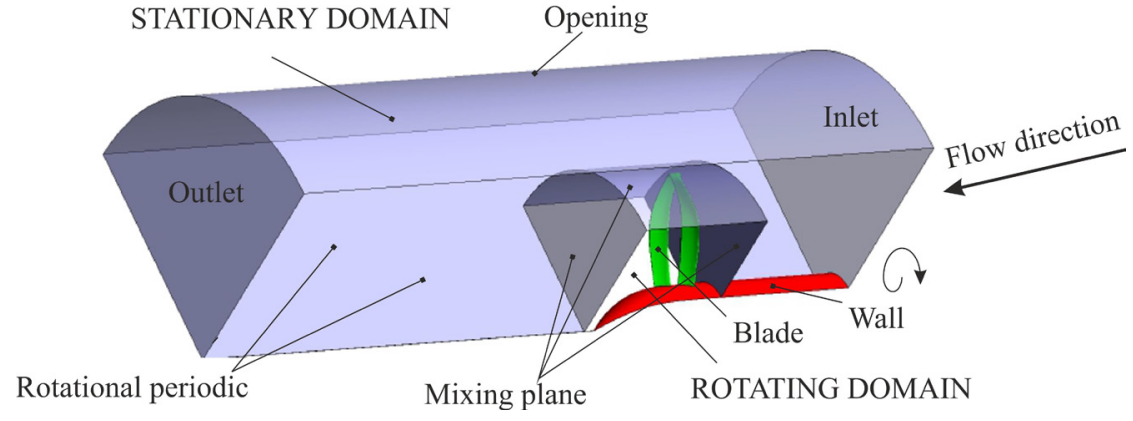

Fig. 5. Topology of the computational domain of the pushing propeller

stream velocity from 0 to $45 \mathrm{~m} / \mathrm{s}$ was investigated.

An analysis of the flow patterns in the tandem propeller with joined blades at a free stream velocity of $20 \mathrm{~m} / \mathrm{s}$ and $0 \mathrm{~m} / \mathrm{s}$ (Fig. 6) showed that at a velocity of $0 \mathrm{~m} / \mathrm{s}$, there is a flow separation in the root part on the front profile of the propeller (Fig. 6,a), which extends along the blade to about a blade height of $0.6 R$; at a flow velocity of $20 \mathrm{~m} / \mathrm{s}$ there is no separation of the flow. In this case, there is a loss of total pressure (Fig. 6, $b$ )

Stage (mixing plane) - when using a boundary condition of this type for the mixing plane, the problem in a stationary formulation is solved in each interacting domain. The calculation results of the flow parameters from neighboring domains are transmitted as boundary conditions and spatially averaged (mixed) at the interface of interacting domains. Such mixing eliminates any instability that may arise due to circular irregularities in the flow field (for example, shock waves, vortex flows, etc.), which leads to a steady-state result. Despite the simplifications inherent in the "mixing plane" model, the obtained solutions can provide reasonable approximations of the time-averaged flow field.

\section{3. Computational grid}

For modeling, a block structured computational grid was developed with a total number of elements from 3.5 million to 8 million. Most of the elements corresponded to a propeller with two blades, and a smaller one to a propeller with four blades. The computational grid was separately constructed for the stationary and rotating domains. The design of the topology and construction of the grid were carried out in the ICEM CFD 15.0 program. The blocks were merged in the ANSYS CFX Pre subprogram. To construct the grid in the wall regions, the parameter $y^{+=1.8}$, the number of layers within the boundary layer is 20 .

\section{Results of the characteristics studies of the tandem propeller with joined blades}

To estimate the efficiency of the propeller, the following parameters were used: advance ratio $J$; power coefficient $C_{P}$; thrust coefficient $C_{T}$ and coefficient of efficiency $\eta$, which are determined by the formulas (10)-(13).

$$
\begin{aligned}
& J=\frac{V_{\infty}}{n D}, \\
& C_{T}=\frac{F_{x}}{\rho_{\infty} n^{2} D^{4}}, \\
& C_{P}=\frac{P_{\text {shaft }}}{\rho_{\infty} n^{3} D^{5}}, \\
& \eta=\frac{F_{x} V_{\infty}}{P_{\text {shaft }}} .
\end{aligned}
$$

In the work, a four-blade tandem propeller with a $406 \mathrm{~mm}$ diameter at a 5,000 rpm speed and free caused by flow separation from the first blade at a flow velocity of $0 \mathrm{~m} / \mathrm{s}$, at a speed of $20 \mathrm{~m} / \mathrm{s}$ the total pressure loss is negligible and is due to profile losses. Losses associated with end tip vortices are absent both at a velocity of $0 \mathrm{~m} / \mathrm{s}$ and at a velocity of $20 \mathrm{~m} / \mathrm{s}$, which is clearly seen from Fig. 6, $a, c$, which in turn indicates the absence of end tip vortex formation.
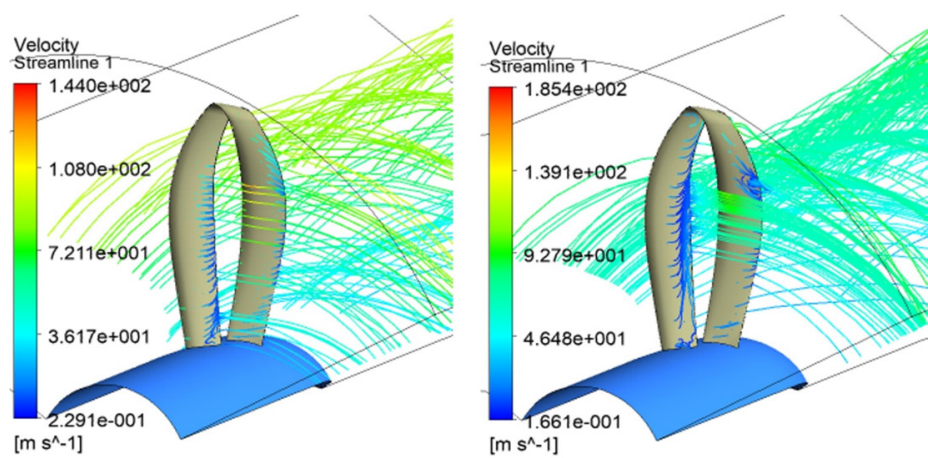

$a$
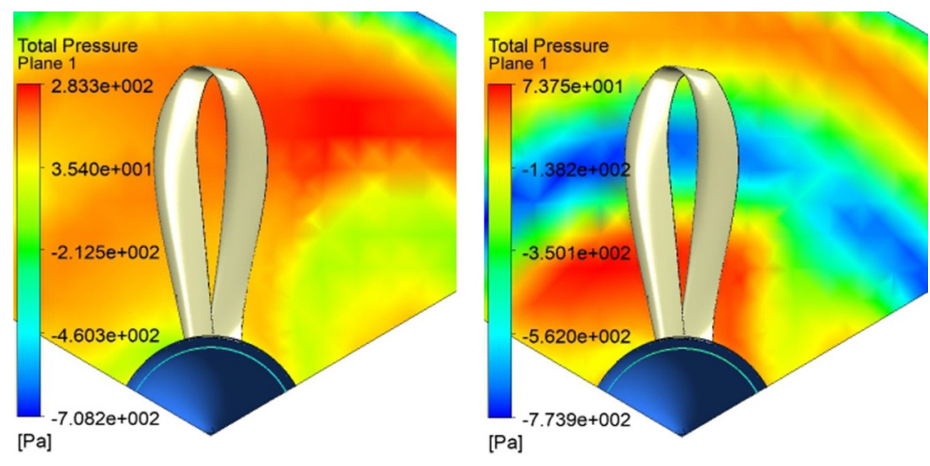

b
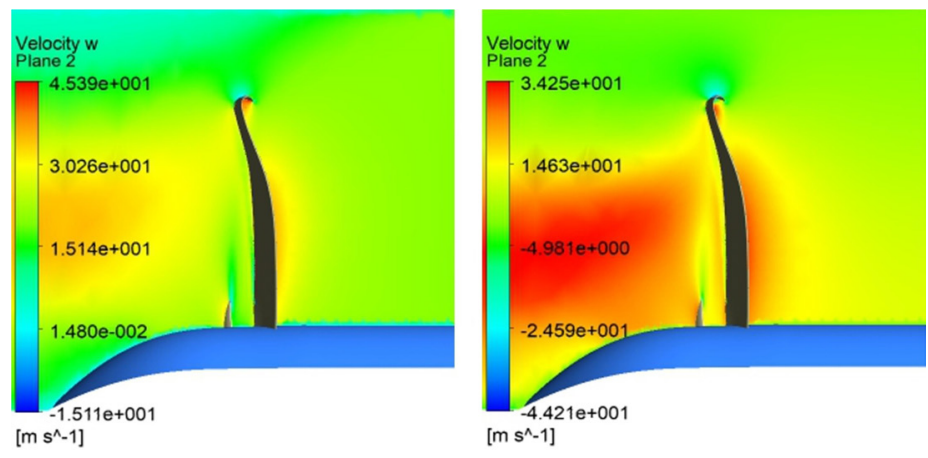

$c$

Fig. 6. Distribution of air flow parameters in the axial and meridional cross-sections at $20 \mathrm{~m} / \mathrm{s}$ (left row) and $0 \mathrm{~m} / \mathrm{s}$ (right row) free stream velocity: $a$ - velocity streamlines; $b$ - total pressure distribution; $c-$ axial velocity distribution 
From the distribution of the total and static pressure in the sections along the height of the blade (Fig. 7) it can be seen that the shadowing of the blades is practically absent. Mutual influence is manifested only in the height range $0.75 R-0.8 R$. In this height range, the rear profile falls into the zone of the aerodynamic trace emanating from the front profile (Fig. 7, $a$, section 0.7). This leads to a decrease in the aerodynamic loading of the rear profile, which is clearly seen from the distribution of static pressure over the profiles (Fig. 8, b). thrust $C_{T}=0.38$ in the case of almost absence of a free stream velocity $(J=0-0.2)$. This indicates that the proposed design of the propeller allows its effective use both during takeoff and in cruising mode.

The study of the characteristics of the tandem propeller as a pusher propulsion device showed a decrease in its thrust by $3.5-4 \%$ in the range of operating modes. At a free stream velocity in the range of $0-10 \mathrm{~m} / \mathrm{s}$, the decrease reached $\approx 4 \%$, in the rest of the range $\approx 3.5 \%$.
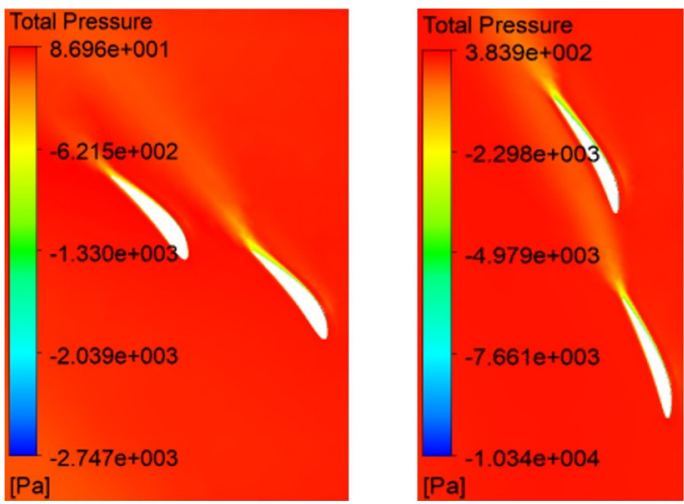

$a$

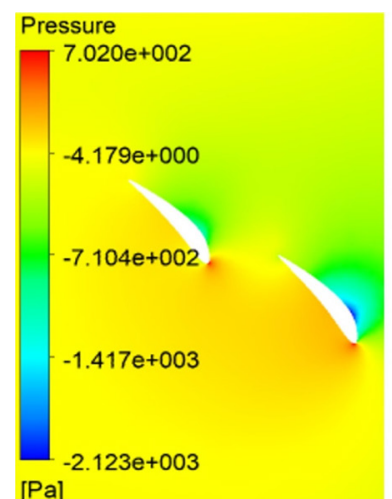

$[\mathrm{Pa}]$

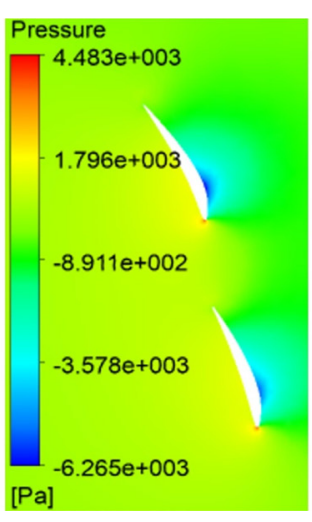

$b$
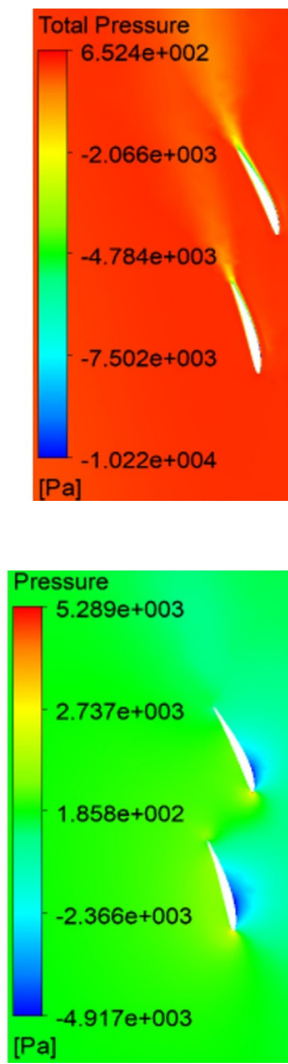

Fig. 7. Changes in flow parameters by the height of the propeller blade in the sections $(0.25 R$ - left row; $0.7 R-$ middle row; $0.9 R$ - right row) at a free stream velocity $-20 \mathrm{~m} / \mathrm{s} ; n=5,000 \mathrm{rpm}$ : $a-$ total pressure, $b$ - static pressure

In general, the proposed arrangement of the profiles of the first and second row of blades makes it possible to ensure their uniform loading along the height of the blade starting from the root and ending with the end section. This is evidenced by the distribution of static pressure over the profiles of the joined blade (Fig. $8, a-c$ ). In all sections of the diagram, the distributions of static pressure along the front and rear profiles have almost the same area.

The applied spiral tip allows the blade to be fully aerodynamically loaded over its entire height, preventing tip flow separation (section 0.9R, Fig. 7, Fig. 8, $c$ ).

As a result of the propeller simulation, its characteristics were also obtained depending on the advance ratio (Fig. 9).

The tandem propeller with joined blades investigated in the present work can be referred to as a high-speed propeller, as it has the maximum efficiency $\eta_{\max }=0.75$ at $J=1.1$, while the maximum operational advance ratio for this propeller $J=1.3$ (Fig. 9). Also from Fig. 9 it can be seen that despite the fact that the propeller is high-speed and has the maximum efficiency at $J=1.1$, it also creates the maximum

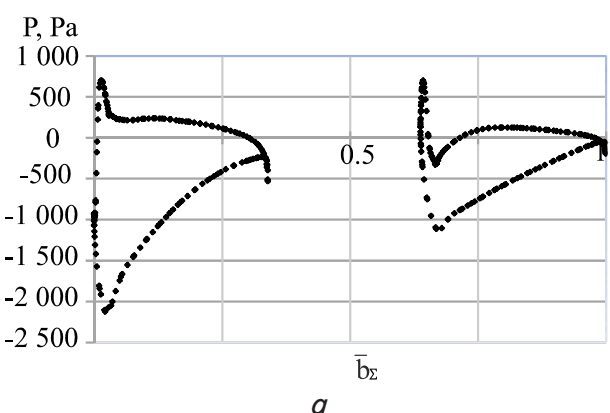

$a$

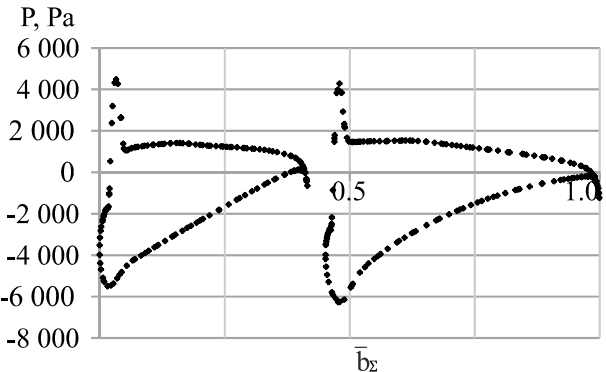

b

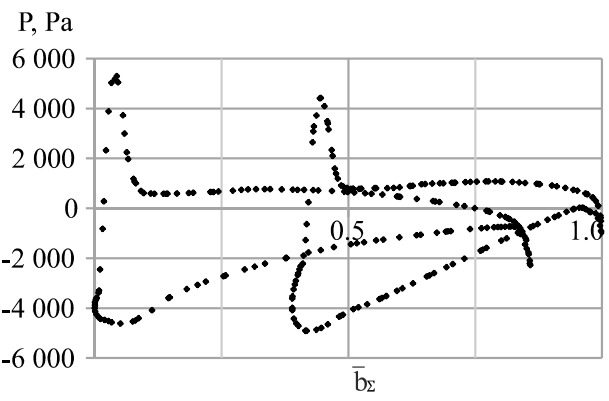

c

Fig. 8. Static pressure distribution over the profiles of the tandem blade: a - section $0.25 R$, $b$ - section $0.75 R, c-$ section $0.9 R$

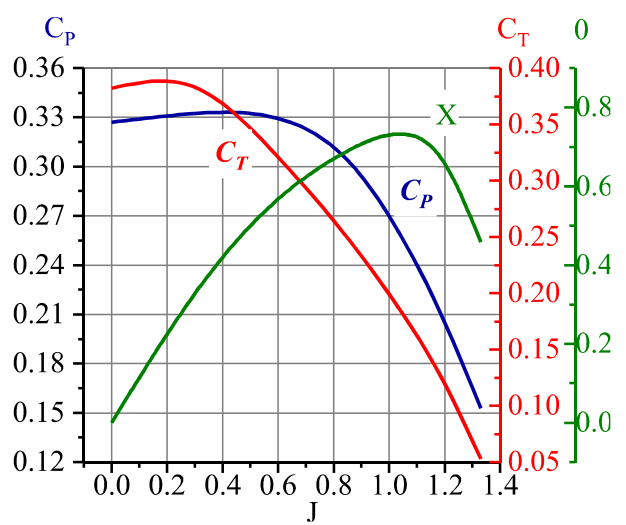

Fig. 9. Characteristic of the propeller with joined blades 
An analysis of the causes of the lower thrust showed that this is due to a significant decrease in the static pressure in the hub part in the area of the spinner pushing propeller (Fig. 10).

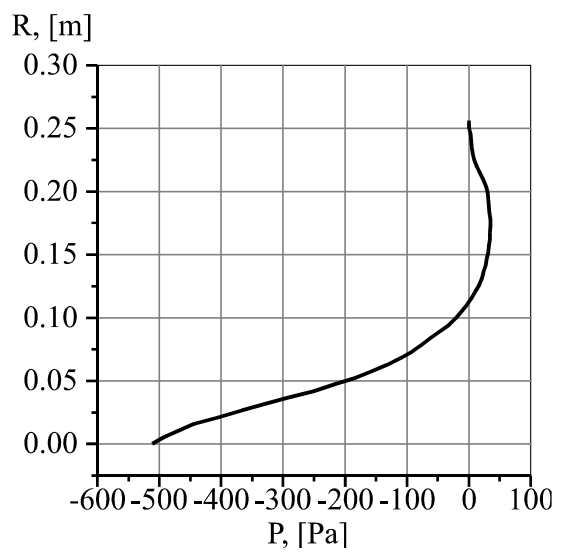

Fig. 10. Changes in static pressure along the height of the blade at the free stream velocity $V_{\infty}=0 \mathrm{~m} / \mathrm{s}$

In general, the tandem arrangement of profiles and the joining of the blades allows you to increase the aerodynamic load on the blade and to reduce the secondary losses caused by the tip vortex flows. On the other hand, hub losses increase leading to underestimation of thrust within 3-4\%. So, in the future, it is necessary to conduct a comprehensive study of the causes that lead to such losses and ways to reduce them.

\section{Discussion of the results of characteristics research of the tandem propeller with joined blades}

The studies confirmed the assumption that the relative position of the profiles of the first and second row of the tandem blade significantly affect the propeller characteristics. The new proposed arrangement of the profiles made it possible to equally load the front and rear blades and to obtain the maximum possible aerodynamic loading for this configuration. From the results of the study, namely, the flow patterns in the interblade channels (Fig. 7) and the pressure distribution over the profiles (Fig. 8) in characteristic sections, it is seen that there is practically no shadowing of the profiles and mutual influence.

The new shape of the connector, which is made in the form of a spiral and connects the blades in the tip part, completely eliminated the tip vortex in the operating range of the propeller. This effect was achieved due to the redistribution of pressure and velocities on the blades of the first and second row, which is reflected in Fig. 6, $c$. The spiral connector made it possible to increase the axial component of the flow velocity in the tip part of the blade and to reduce the tangential component, which leads to the flowing and twisting of the flow into the vortex bundles.

In general, the proposed measures made it possible to obtain a propeller efficiency of $75 \%$, which is a fairly good indicator for propellers operating at low Reynolds numbers. This was primarily achieved due to the almost complete reduction of tip losses (by applying a spiral connector) and secondly by increasing the aerodynamic loading of the tandem blade (by applying a new arrangement of profiles).
However, not only positive effects should be noted. The new arrangement of tandem blade profiles has led to a significant increase in hub losses in the case of a pushing propeller. Hub losses led to a reduction in thrust within 3-4\%. This decrease is due to the presence of a vacuum zone around the propeller spinner.

To conduct numerical studies, a computational model of the tandem propeller in a periodic setting was developed. A feature of the model is that it allows taking into account and evaluating the flow around the hub and tip parts of the propeller and spinner. The accuracy of the model was evaluated on a test classic single-row propeller with geometric dimensions similar to those of the studied propeller. The disadvantages of the model include the fact that it was performed in a periodic setting, which makes it impossible to conduct propeller studies with oblique blowing.

When applying research results in practice, one should take into account the technological capabilities of manufacturing tandem propellers with the proposed changes. This is primarily due to the shape of the blades and spiral connector. It may be that the aerodynamically optimal shape cannot be made.

The disadvantages of the study include the fact that only one configuration of the arrangement of the first and second rows profiles of the tandem blade is considered in the work, but the geometric parameters of the mutual arrangement of the profiles that would affect the characteristics of the propeller are not indicated. Also, the results of experimental studies are missing, which reduces the reliability of the results.

In further studies, it is necessary to focus on determining the factors affecting the hub losses of tandem propellers with joined blades, which will allow developing procedures and methods to reduce them. It is also necessary to develop theoretical foundations for determining the rational arrangement of profiles and profiling of the spiral connector. This will allow creating engineering techniques for profiling tandem propellers. Acoustic studies of tandem propellers can also be of considerable interest, since the issue of acoustic emission is one of the most relevant in the last decade.

\section{Conclusions}

1. A geometric model of the tandem propeller is developed taking into account the features of the flow around the first and second rows of blade profiles, which differs in the new location of the profiles of the first and second rows of the blade along its height. Starting from the root part and to $0.75-0.8 R$ of the blade height, the arrangement of the profiles is applied according to the type of form $-B$, and in the tip part - according to the type of form $-H$. To join the blades in the tip part, a new spiral-shaped connector was used, which ensures a smooth connection and untwisting of the tip vortex.

2. A computational model of the tandem propeller with joined blades in a periodic formulation was developed taking into account the features of the shape of the tandem blade. The computational domain included two domains - stationary and rotor using mixing interfaces of the "mixing plane" type. The block structured computational grid with a total number of elements of 7.5 million was applied. During the simulation, unsteady Reynolds averaged Navier-Stokes equations closed by the SST Menter turbulence model were 
solved. Such a model made it possible to conduct numerical studies of the propeller with acceptable speed and accuracy. The calculation error was on average $8-12 \%$.

3 . The results of the numerical study of the tandem propeller with joined blades showed that the new arrangement of the profiles of the first and second rows provides a uniform load of the blade along its height, while no shading of one row of blades by another occurs. The spiral connector, which joins the blades, ensures the utilization of the final vortex and reduces secondary losses. The developed propeller has an efficiency of $75 \%$, which is a very good indicator for propellers operating at low Reynolds numbers. A decrease in the thrust of the pushing propeller by $3-4 \%$ was detected, due to the vacuum zone in the hub part.

\section{References}

1. Berry, J. D., Mineck, R. E. (1980). Wind-tunnel test of an articulated helicopter rotor model with several tip shapes. NASA. Technical Rcport 79-49, 92

2. Gyatt, G. W., Lissama, P. P. S. (1985). Development and Testing of tip devises for horizontal axis wind turbines. Report NASA CR174991, 79 .

3. Redman, B., Spindler, P. et. al. (2005). Proplet Propeller Design/Build/Test. Final Report. Available at: http://phil.zatetic.com/ school/AAE_490T_Report.pdf

4. Wang, Y., Li, Q., Eitelberg, G., Veldhuis, L. L. M., Kotsonis, M. (2014). Design and numerical investigation of swirl recovery vanes for the Fokker 29 propeller. Chinese Journal of Aeronautics, 27 (5), 1128-1136. doi: https://doi.org/10.1016/j.cja.2014.03.009

5. Zha, G., Paxton, C. et. al. (2002). Pat. No. US 20040126241 A1. Forward swept high efficiency airplane propeller blades. No. 10/330,225; declareted: 30.12.2002; published: 01.06.2004. Available at: https://patentimages.storage.googleapis.com/e2/21/21/bc6c3a5b58cc9e/US20040126241A1.pdf

6. Vad, J., Halász, G., Benedek, T. (2014). Efficiency gain of low-speed axial flow rotors due to forward sweep. Proceedings of the Institution of Mechanical Engineers, Part A: Journal of Power and Energy, 229 (1), 16-23. doi: https://doi.org/10.1177/0957650914552817

7. Shpadi, A. L. (2012). Pat. No. RU 2509683 C2. Propeller. No. 2012106998/11; declareted: 27.02.2012; published: 20.03.2014, Bul. No. 8. Available at: http://www.freepatent.ru/images/patents/508/2509683/patent-2509683.pdf

8. Polacsec, R. R. (2002). Pat. No. US 6948910 B2. Spiral-Based Axial Flow Devices. No. 10/194,386; declareted: 12.07.2002; published: 27.09.2015. Available at: https://patentimages.storage.googleapis.com/23/3a/71/0d774322c3b32a/US6948910.pdf

9. Silivano, D. (1998). Pat. No. US 6099256A. Three dimensional figure eight propeller/impeller blade apparatus. No. 09/137,565; declareted: 20.08.1998; published: 08.08.2000. Available at: https://patentimages.storage.googleapis.com/72/63/3d/4cb20bfdd8a185/US6099256.pdf

10. Adriansson, S. (2013). Design and testing of a box-bladed propeller. Gothenburg. Available at: http://publications.lib.chalmers.se/ records/fulltext/219510/219510.pdf

11. Capitao Patrao, A., Avellán, R., Lundbladh, A., Grönstedt, T. (2016). Wake and Loss Analysis for a Double Bladed Swept Propeller. Volume 1: Aircraft Engine; Fans and Blowers; Marine. doi: https://doi.org/10.1115/gt2016-56540

12. Capitao Patrao, A., Grönstedt, T., Avellán, R., Lundbladh, A. (2018). Wake energy analysis method applied to the Boxprop propeller concept. Aerospace Science and Technology, 79, 689-700. doi: https://doi.org/10.1016/j.ast.2018.06.018

13. Capitao Patrao, A. (2018). On the Aerodynamic Design of the Boxprop. Gothenburg, 74.

14. Shen, C., Qiang, X., Teng, J. (2012). Numerical and experimental investigation of an axial compressor flow with tandem cascade. Journal of Thermal Science, 21 (6), 500-508. doi: https://doi.org/10.1007/s11630-012-0574-x

15. Zhang, L., Wang, S. (2017). A combination application of tandem blade and endwall boundary layer suction in a highly loaded aspirated compressor outlet vane. Proceedings of the Institution of Mechanical Engineers, Part A: Journal of Power and Energy, 232 (2), 129-143. doi: https://doi.org/10.1177/0957650917722455

16. Qiushi, L., Hong, W., Sheng, Z. (2010). Application of Tandem Cascade to Design of Fan Stator with Supersonic Inflow. Chinese Journal of Aeronautics, 23 (1), 9-14. doi: https://doi.org/10.1016/s1000-9361(09)60181-3

17. Menter, F. R. (1994). Two-equation eddy-viscosity turbulence models for engineering applications. AIAA Journal, 32 (8), 1598 1605. doi: https://doi.org/10.2514/3.12149 